Bangladesh J. Plant Taxon. 18(1): 73-76, 2011 (June)

(C) 2011 Bangladesh Association of Plant Taxonomists

- Short communication

\title{
OCCURRENCE OF NITROGEN-FIXING CYANOBACTERIA DURING DIFFERENT STAGES OF PADDY CULTIVATION
}

\author{
KaUSHAL Kishore ChOUdHARY* \\ Department of Botany, B.R.A. Bihar University, Muzaffarpur-842001, Bihar, India
}

Keywords: Cyanobacteria; Diversity; Nitrogen-fixing; Rice fields; North Bihar.

Rapid decline in soil fertility and productivity due to excessive application of chemical fertilizer particularly nitrogen and its increasing cost has induced to develop alternate biological sources of nitrogenous fertilizers (Boussiba, 1991). Biological fertilizers maintain the nitrogen status of the soils and helps in optimum crop production to meet the demand of increasing human populations while maintaining the agricultural practices sustainable. With establishment of agronomic potential of cyanobacteria (Singh, 1950), these photosynthetic prokaryotes were applied and studied for enrichment of different living ecosystems with nitrogenous compounds. Cyanobacteria are endowed with a specialized structure 'heterocyst' with 'nitrogenase complex' capable of converting unavailable sources of molecular nitrogen into nitrogenous compounds (Ernst et al., 1992). The ability of cyanobacteria to fix atmospheric nitrogen is increasing concern worldwide to exploit this tiny living system for nitrogenous fertilizers for sustainable agriculture practices.

Advances in cyanobacteria have revealed their significant contribution in promoting the fertility of the soil and water including marine by adding nitrogen and phosphorus. Cyanobacteria contribute phosphorus to the soil by mobilizing the insoluble organic phosphates present in the soil with enzyme 'phosphatses' (Whitton et al., 1991). Moreover, cyanobacteria enhance the water holding capacity by adding polysaccharidic material to the soil (Richert et al., 2005) that increases the soil aggregation property. Cyanobacteria have also been reported to excrete growth promoting substances into the soil (Karthikeyan et al., 2007). In view of cyanobacterial potential, distribution and diversity of nitrogen-fixing cyanobacteria in rice fields has been extensively studied (Khan et al., 1994; Prasanna and Nayak, 2007; Begum et al., 2008; Choudhary, 2009; Choudhary and Bimal, 2010). The present study has been aimed to enumerate the nitrogen-fixing cyanobacteria belonging to family Microchaetaeceae, Rivulariaceae and Scytonemataceae (Nostocales) in rice fields of north Bihar.

Study sites: The study was conducted in certain rice fields of Muzaffarpur district situated at latitude $26^{\circ} 7^{\prime} 12^{\prime \prime} \mathrm{N}$ and longitude $85^{\circ} 24^{\prime} 0^{\prime \prime} \mathrm{E}$ of North Bihar. Documentation of proposed cyanobacterial diversity was conducted during rice cultivation cycle by assuming that rice fields witnesses a gradual decrease in temperature and nutrient status with progress in cultivation cycle.

\footnotetext{
*E-mail: kkc1970@gmail.com
} 
Enumeration of cyanobacterial diversity: Heterogeneous biomasses of cyanobacteria growing on moist soil surfaces, floating on the water bodies and attached to rice plants were randomly collected from upland and lowland rice fields on $20^{\text {th }}, 40^{\text {th }}$ and $60^{\text {th }}$ days of rice seedlings plantation.

Table 1. Distribution of nitrogen-fixing cyanobacteria belonging to family Microchaetaceae, Rivulariaceae and Scytonemataceae (Nostocales) during different stages of paddy cultivation. (+ = Presence; - = Absence; $\mathbf{R}=$ Rare)

\begin{tabular}{|c|c|c|c|c|c|}
\hline $\begin{array}{l}\text { Sl. } \\
\text { No. }\end{array}$ & Species & Family & $\begin{array}{c}20 \\
\text { days }\end{array}$ & $\begin{array}{c}40 \\
\text { days }\end{array}$ & $\begin{array}{c}60 \\
\text { days }\end{array}$ \\
\hline 1. & Calothrix fusca (Kützing) Bornet \& Flahault & Rivulariaceae & - & - & $\mathrm{R}$ \\
\hline 2. & Calothrix javanica De Wildeman & Rivulariaceae & + & + & + \\
\hline 3. & Calothrix viguieri Frémy & Rivulariaceae & - & - & + \\
\hline 4. & Fortiea incerta Skuja & Microchaetaceae & - & - & + \\
\hline 5. & Gloeotrichia echinulata J.E. Smith ex P.G. Richter & Rivulariaceae & - & - & + \\
\hline 6. & Gloeotrichia indica Schmidle & Rivulariaceae & - & - & + \\
\hline 7. & Gloeotrichia kurziana Zeller & Rivulariaceae & + & + & $\mathrm{R}$ \\
\hline 8. & Gloeotrichia longicauda Schmidle & Rivulariaceae & - & + & + \\
\hline 9. & $\begin{array}{l}\text { Gloeotrichia natans (Hedwig) Rabenhorst ex } \\
\text { Bornet \& Flahault }\end{array}$ & Rivulariaceae & + & + & - \\
\hline 10. & Gloeotrichia pilgeri Schmidle & Rivulariaceae & - & - & + \\
\hline 11. & $\begin{array}{l}\text { Gloeotrichia pisum (C. Agardh) Thuret ex Bornet } \\
\text { \& Flahault }\end{array}$ & Rivulariaceae & - & - & + \\
\hline 12. & Gloeotrichia raciborskii var conica Dixit & Rivulariaceae & - & - & + \\
\hline 13. & Microchaete grisea Thuret & Microchaetaceae & - & - & + \\
\hline 14. & Microchaete tenera Thuret ex Bornet & Microchaetaceae & + & + & + \\
\hline 15. & Microchaete uberrima N. Carter & Microchaetaceae & - & + & + \\
\hline 16. & Microchaete violacea Frémy & Microchaetaceae & - & - & $\mathrm{R}$ \\
\hline 17. & Plectonema notatum Schmidle & Scytonemataceae & - & + & + \\
\hline 18. & $\begin{array}{l}\text { Plectonema tomasinianum (Kützing) Gomont ex } \\
\text { Gomont }\end{array}$ & Scytonemataceae & - & - & $\mathrm{R}$ \\
\hline 19. & Rivularia aquatica De Wildeman & Rivulariaceae & - & + & + \\
\hline 20. & $\begin{array}{l}\text { Rivularia beccariana (De Notaris) Bornet \& } \\
\text { Flahault }\end{array}$ & Rivulariaceae & - & - & + \\
\hline 21. & Rivularia manginii Fremy & Rivulariaceae & - & - & $\mathrm{R}$ \\
\hline 22. & Scytonema cincinnatum (Kützing) Thuret & Scytonemataceae & - & - & + \\
\hline 23. & Scytonema fritschii S. L. Ghose & Scytonemataceae & + & + & + \\
\hline 24. & Scytonema pascheri Bharadwaja & Scytonemataceae & - & - & $\mathrm{R}$ \\
\hline 25. & Scytonema simplex Bharadwaja & Scytonemataceae & + & + & + \\
\hline 26. & Scytonema varium Kützing & Scytonemataceae & - & + & + \\
\hline 27. & Tolypothrix tenuis (Kützing) & Scytonemataceae & - & + & + \\
\hline
\end{tabular}

The samples were collected in culture tube $(50 \mathrm{ml})$ with $20 \mathrm{ml}$ nutrient medium (Rippka et al., 1979) and brought to the laboratory. The taxonomic enumeration of cyanobacterial 
species diversity was performed microscopically with collected samples (fresh materials) in the laboratory. The taxa were identified using morphological features such as cell size, shape, morphology of the terminal cell, presence or absence of heterocysts and akinetes (Desikachary, 1959).

Twenty-seven nitrogen-fixing cyanobacterial species belonging to Microchaetaeceae, Rivulariaceae and Scytonemataceae (Nostocales) were recorded from field samples collected on $20^{\text {th }}, 40^{\text {th }}$ and $60^{\text {th }}$ day of rice seedling plantation. Out of 27 species, 8 were represented by Gloeotrichia, 5 by Scytonema, 4 by Microchaete, 3 by Calothrix and Rivularia each, 2 by Plectonema and 1 by Tolypothrix and Fortiea each. Cyanobacterial species diversity was represented by 26 species ( 8 genera) on $60^{\text {th }}$ day, 12 species ( 7 genera) on $40^{\text {th }}$ day and 6 species (4 genera) on $20^{\text {th }}$ day of rice seedling plantation with some common forms (Table 1). The gradual increase in diversity of nitrogen-fixing cyanobacteria with progress in paddy cultivation was assumed to be related with increase in rice canopy that causes a decrease in light intensity reaching to the surface of the soil and depletion of nutrients particularly nitrogen. Similar distribution pattern of cyanobacterial diversity was reported for fertilized and unfertilized rice fields (Choudhary and Bimal, 2010). Granhall et al. (1987) reported the predominance of nitrogen fixation and cyanobacterial number under low concentration of nitrogen fertilizer. Finally, it might be proposed that documentation on nitrogen-fixing cyanobacteria and their application in the rice fields can be used for management of nitrogen fertilizer at different stages of paddy cultivation for sustainable agricultural practices by making the field environment supportive for nitrogen-fixers.

\section{Acknowledgements}

The author is grateful to Head, Department of Botany, B.R.A. Bihar University, Muzaffarpur, Bihar for providing laboratory facilities. The author is also thankful to Prof. R. Bimal for his support.

\section{References}

Begum, Z.N.T., Mandal, R. and Amin, F.B. 2008. Quantification and nitrogen fixation of cyanobacteria in rice field soils of Bangladesh. Bangladesh J. Bot. 37(2): 183-188.

Boussiba, S. 1991. Nitrogen fixing cyanobacteria potential uses. Plant \& Soil 137(1): 177-180.

Choudhary, K.K. 2009. Occurrence of Chroococcaceae during rice cultivation in northern Bihar, India. Bangladesh J. Plant Taxon. 16(1): 57-63.

Choudhary, K.K. and Bimal, R. 2010. Distribution of nitrogen-fixing cyanobacteria (Nostocaceae) during rice cultivation in fertilized and unfertilized paddy fields. Nord. J. Botany 28(1): 100-103.

Desikachary, T.V. 1959. Cyanophyta. Indian Council of Agricultural Research, New Delhi, India. pp. 1-686. 
Ernst, A., Black, T., Cai, Y., Panoff, J.M., Tiwari, D.N. and Wolk, C.P. 1992. Synthesis of nitrogenase in mutants of the cyanobacterium Anabaena sp. PCC 7120 affected in heterocyst development. J. Bacteriol. 174(19): 6025-6032.

Granhall, U., Kulassoriya, S.A., Hirimburegama, W.K., de Silva, R.S.Y. and Lindberg, T. 1987. Nitrogen fixation in some rice soils in Sri Lanka. World J. Microb. Biotech. 3(4): 67-88.

Karthikeyan, N., Prasanna, R., Nain, L. and Kaushik, B.D. 2007. Evaluating the potential of plant growth promoting cyanobacteria as inoculants for wheat. Eur. J. Soil Biol. 43(1): 23-30.

Khan, Z.U.M., Begum, Z.N.T., Mandal, R. and Hossain, M.Z. 1994. Cyanobacteria in rice soils. World J. Microb. Biotech. 10(3): 296-298.

Prasanna, R. and Nayak, S. 2007. Influence of diverse rice ecologies on cyanobacterial diversity and abundance. Wetl. Ecol. Management 15(2): 127-134.

Richert, L., Golubic, S., Le Guédès, R., Ratiskol, J., Payri, C. and Guezennec, J. 2005. Characterization of Exopolysaccharides produced by cyanobacteria isolated from Polynesian microbial mats. Curr. Microbiol. 51(6): 379-384.

Rippka, R., Josette, D., Waterbury, J.B., Herdman, M. and Stanier, R.Y. 1979: Generic assignments, strain histories and properties of pure cultures of cyanobacteria. J. Gen. Microbiol. 111(1): 1-61.

Singh, R.N. 1950. Reclamation of usar lands in India through blue-green algae. Nature 165(4191): 325-326.

Whitton, B.A., Grainger, S.L.J., Hawley, G.R.W. and Simon, J.W. 1991. Cell-bound and extracellular phosphatase activities of the cyanobacterial isolates. Microbial Ecol. 21(1): 85-98.

(Manuscript received on 26 September 2010; revised on 3 March 2011) 